\title{
Long-term effect of Mali phosphate rock on the grain yield of interspecifics and saltiva rice cultivars on acid soil in a humid forest zone of Côte d'Ivoire
}

\author{
B. KONÉ ${ }^{1 *}$, A. YAO-KOUAMÉ ${ }^{2}$, F. SORHO ${ }^{4}$, S. DIATTA $^{3}$, M. SIÉ $^{3}$ and \\ A. OGUNBAYO ${ }^{3}$
}

${ }^{1}$ Africa Rice Center, BP 2031 Cotonou 01, Bénin ; Tel : 229 21350188 ; Fax : 229 21350556; E-mail : b.kone@cgiar.org; and Cocody University,UFR des Sciences de la Terre et des Ressources Minières, Laboratoire de Pédologie Appliquée, 22 BP 582 Abidjan 22, Côte d'Ivoire. Tel : 22507499875 ; Fax : 225 21356345; E-mail : kbrahima@hotmail.com

${ }^{2}$ Cocody University, UFR des sciences de la terre et des ressources minières, laboratoire de pédologie appliquée, 22 BP 582 Abidjan 22, téléphone : 22507381959 ; Fax: 22521356345 Abidjan, Côte d'Ivoire. ${ }^{3}$ Africa Rice Center, BP 2031 Cotonou 01, Bénin. Tel: 229 21350188; Fax: 22921350556.

${ }^{4}$ Cocody-Abidjan University, UFR Biosciences, Laboratoire de Physiologie Végétale, 22 BP 582, Tel+22502639445, E-mail: sorho.fatogoma@univ-cocody.ci

*Corresponding author, E-mail: b.kone@cgiar.org

\begin{abstract}
To generate knowledge of upland rice intensification in West Africa, the grain yields of four interspecific cultivars (V2 = WAB450-1-B-P-38-HB; V3 = WAB450-11-1-P-40-HB; V4 = WAB450-11-1-P40-1-H; and V5 = WAB450-24-3-2-P-18-HB) were compared with that of a soil acidity tolerant sativa (WAB 56-104 = V1) on acid soil at Man in the humid forest zone in Côte d'Ivoire during five cropping seasons (1998, 1999, 2000, 2001 and 2002). Nitrogen and potassium were annually applied at 100 and $50 \mathrm{~kg} \mathrm{ha}^{-1}$ respectively. Mali phosphate rock from Tilemsi was applied once in 1998 at $0,150,300$ and $450 \mathrm{~kg} \mathrm{P} \mathrm{ha}^{-1}$ in a randomized complete block design with three replications. The results revealed a grain yield ranging from $0.5 \mathrm{t}^{-1}$ to $2.6 \mathrm{t}$ $\mathrm{ha}^{-1}$ with highest productivity of interspecific cultivars $\mathrm{V} 3$ and $\mathrm{V} 4$ even at $0 \mathrm{~kg} \mathrm{P}$ ha ${ }^{-1}$ compared to acid tolerant saltiva (V1). Annual optimum rates of $\mathrm{P}$ application were determined at 31.5 and $45 \mathrm{~kg} \mathrm{P} \mathrm{ha}^{-1}$ respectively for V3 and V4. Applying Mali PR at 31.5 and $45 \mathrm{~kg} \mathrm{P}^{-1}$ respectively for V3 and V4 was recommended for upland rice intensification in the humid forest zone of Côte d'Ivoire.

(C) 2010 International Formulae Group. All rights reserved.
\end{abstract}

Keywords: Mali phosphate rock, rice, Côte d'Ivoire, interspecific, acid soil.

\section{INTRODUCTION}

Low phosphorus status is one of the major constraints for optimum crop production in highly weathered tropical acid soils. These soils exhibit high acidity with high aluminium and iron minerals; hence most of phosphate $(\mathrm{P})$ fertilizers applied to these soils are retained in the soils and unavailable to plants. Despite the widespread problem of low plant available $\mathrm{P}$ in tropical acid soils (Semoka and Kalumuna, 2000), the use of P fertilizers is very limited often attributed to high cost of synthetic mineral fertilizers (Szilas et al., 2007a). Therefore, the use of local phosphate rocks (PRs) as fertilizers to acid soils low in available $\mathrm{P}$ is one of the ways to improve soil available $\mathrm{P}$.
Moreover, it has been reported that the application of reactive PRs to soil increased bioavailable soil $\mathrm{P}$, exchangeable calcium and magnesium, soil $\mathrm{pH}$ and, as consequence, reduced aluminium and iron toxicities (Fardeau and Zapata, 2002; Szilas et al., $2007 \mathrm{~b}$ ). These conditions improve $\mathrm{P}$ nutrition of upland rice for increasing rice production in acid soil. However, most of $\mathrm{P}$ studies on nutrition of upland rice on acid soil in humid forest zone of Africa were related to imported soluble phosphate and saltiva rice variety (Sahrawat et al., 1997; 2001). Only limited work done has been carried out on PR application for rice production. For example, Somado et al. (2003) worked on Mali PR which is considered as most suitable for crop 
production in West Africa (Debrah, 2000). Despite of the high adoption rate of interspecific cultivars by farmers in rice-based systems of Africa (Diagne, 2008), there is limited knowledge of their P-nutrition. However, differences in cultivar can affect PR efficiency (Flash et al., 1987). Therefore, knowledge of P-nutrition of interspecific cultivars is needed to improve rice production in Africa.

Residual effect of PR applied once in large amount can satisfy rice $P$ requirement of rice for a period of time, especially for the interspecifics due to their indigenous character and the tolerance of soil acidity of their parents Oryza glaberrima (CG14) and Oryza saltiva (WAB56-104) from Africa and Asia (Jones et al., 1997). Infact, the interspecific progeny can improve tolerance to soil acidity more than their parents; especially the $O$. sativa. Therefore, the use of interspecific cultivars can be an opportunity to improve $\mathrm{P}$ nutrition and rice production on acid soil of West Africa.

This study compared the responses to Mali PR (Ma) applied once at 0, 150, 300 and $450 \mathrm{~kg} \mathrm{P} \mathrm{ha}{ }^{-1}$ in 1998 for a period of five years in humid forest zone of Côte d'Ivoire on a hyperdystric ferralsol by four interspecific cultivars and WAB56-104 (O. sativa). The objective is to determine optimum rate of $\mathrm{P}$ application using Mali PR and the most adapted cultivar to soil acidity for sustainable upland rice production in Côte d'Ivoire.

\section{MATERIALS AND METHODS}

The experimental site

The experiment was conducted at the research station of the National Center for Agronomic Research (NCAR) at MAN in Côte d'Ivoire $\left(7^{\circ} 2 \mathrm{~N}, 7^{\circ} 4 \mathrm{~W} ; 500 \mathrm{~m}\right.$ asl) from 1998 to 2002. The site is located in tropical humid forest agro-ecosystem with a mono modal rainfall pattern. Rainfall during the growing seasons was $1020 \mathrm{~mm}$ in 1998 (with missing data in August), $1124.4 \mathrm{~mm}, 1063$ $\mathrm{mm}, 1179 \mathrm{~mm}$ and $1204 \mathrm{~mm}$ respectively in 1999, 2000, 2001 and 2002. The soil was characterized as hyperdystric ferralsol having a low inherent fertility with a low $\mathrm{pH}(<5)$ and very low available $\mathrm{P}$ content (Table 1$)$. The experiment was preceded by a 3-year bush fallow.

\section{Field experimentation}

Fallow land of $1000 \mathrm{~m}^{2}$ was cleared with a cutlass and cleaned of plant debris. Ploughing and spraying operations were mechanized in the first year (1998) while manual operations were done in the other years (1999, 2000, 2001 and 2002). A $4 \times 5$ factorial experiment comprising four $\mathrm{P}$ application rates $(0,150,300$ and $450 \mathrm{~kg} \mathrm{P}$ ha ${ }^{1}$ ), and five cultivars, was conducted for five years in a randomized complete block design with three replications. Tilemsi PR (45\% $\mathrm{CaO}, 5.3 \% \mathrm{Fe}_{2} \mathrm{O}_{3}, 1.3 \% \mathrm{Al}_{2} \mathrm{O}_{3}, 2.9 \% \mathrm{~F}$ and 27.5-31 \% $\mathrm{P}_{2} \mathrm{O}_{5}$ ) from Mali was used as $\mathrm{P}$ source for five cultivars including four interspecifics (V2 = WAB450-1-B-P-38-HB; $\mathrm{V} 3=\mathrm{WAB} 450-11-1-\mathrm{P}-40-\mathrm{HB} ; \mathrm{V} 4=$ WAB450-11-1-P-40-1-H; V5 = WAB450-243-2-P-18-HB) and a saltiva (WAB 56-104 = V1) earlier reported to be tolerant to soil acidity (ADRAO, 2000) and P-efficient (Sahrawat et al., 2003). This sativa was considered as the check cultivar. Only V2 (NERICA1) is among the new generation of 18 interspefics named NERICA.

Rice seeds were sown per hill of 5 grains at a spacing of $20 \mathrm{~cm} \times 20 \mathrm{~cm}$ thinned to 3 plants at 7-10 days after emergency (DAE) in micro plots of $3 \mathrm{~m} \times 5 \mathrm{~m}$. Annually, $30 \mathrm{~kg} \mathrm{~N} \mathrm{ha}^{-1}$ (Urea) and $50 \mathrm{~kg} \mathrm{~K} \mathrm{ha}^{-1}(\mathrm{KCl})$ were applied before sowing the rice seeds. Additional $35 \mathrm{~kg} \mathrm{~N}^{-1}$ was applied at early tillering and heading. Two manual weedings were carried out at 21 and $45 \mathrm{DAE}$.

Table 1: Some chemical characteristics of composite soil sample taken from 0-20 cm depth before start of the experiment in 1998.

\begin{tabular}{lc}
\hline Soil characteristics & Magnitude \\
\hline $\mathrm{pH}($ water $)$ & 4.9 \\
Organic C $\left(\mathrm{g} \mathrm{kg}^{-1}\right)$ & 13.5 \\
Total N $\left(\mathrm{mg} \mathrm{kg}^{-1}\right)$ & 950 \\
Available P - Bray I $\left(\mathrm{mg} \mathrm{kg}^{-1}\right)$ & 2.8 \\
$\mathrm{~K}\left(\mathrm{cmol}_{+} \mathrm{kg}^{-1}\right)$ & 0.22 \\
$\mathrm{Ca}\left(\mathrm{cmol}_{+} \mathrm{kg}^{-1}\right)$ & 0.12 \\
$\mathrm{Mg}\left(\mathrm{cmol}_{+} \mathrm{kg}^{-1}\right)$ & 0.48 \\
\hline
\end{tabular}




\section{Soil analysis}

Before the trial, a composite soil sample was collected with an auger at each corner and the centre in a micro plot at the 0 $20 \mathrm{~cm}$ depth. The samples were air-dried and sieved through $2 \mathrm{~mm}$ screen for laboratory analysis. The analytical procedures of the International Institute for Tropical Agriculture (1989) was used for the determination of soil pH (water), soil organic C, total $\mathrm{N}$, available $\mathrm{P}$ (Bray I), and exchangeable calcium, potassium and magnesium contents (Table 1).

\section{Data collection}

The rice was harvested from a net area of $8 \mathrm{~m}^{2}$ for each treatment leaving out the two border lines. After threshing and drying, the straw and grains were separately weighed, and grain yield (GY) was corrected to a $14 \%$ moisture basis.

\section{Statistical analysis}

Grain yield was analyzed using linear model procedure to determine the annual mean value per $\mathrm{P}$ rate according to cultivars. Means were separated using the least significant difference (LSD) at $\alpha=0.05$. Multiple comparisons were also made between the yield grand means of years and cultivars as well as between the grain yields and $\mathrm{P}$ rates. By surface response analysis, rice grain yield response to $P$ rates was investigated through the regression output and the response curves. SAS (version 2001) was used for these analyses.

\section{RESULTS}

\section{Rice grain yield}

The grain yield (Table 2) induced by $\mathrm{P}$ rates in 1998 was ranging from 1.3 to $2.5 \mathrm{t}$ ha 1 except control treatment $\left(0.75-1.7 \mathrm{t} \mathrm{ha}^{-1}\right)$. In the other years (1999-2000-2001 and 2002), the yields obtained were generally bellow $2 \mathrm{t} \mathrm{ha}^{-1}$ whenever, in the $2^{\text {nd }}$ and $3^{\text {rd }}$ years, 2 to $2.3 \mathrm{t} \mathrm{ha}^{-1}$ could be observed especially for 300 and $450 \mathrm{~kg} \mathrm{P} \mathrm{ha}{ }^{-1}$. The interspecific cultivars V3 $\left(0.9-2.3 \mathrm{tha}^{-\mathrm{i}}\right)$ and V4 $\left(0.9-2.6 \mathrm{t} \mathrm{ha}^{-1}\right)$ have the highest grain yield compared with the saltiva-V1 $(1.3-1.6$ $\mathrm{t} \mathrm{ha}^{-1}$ ) excluding the control treatment. From the interaction $(\mathrm{P}$ rate $\times$ cultivar) effect, the yield was ranging from $0.4\left(\mathrm{~V} 5,0 \mathrm{~kg} \mathrm{P} \mathrm{ha}^{-1}\right.$, 1999 and V5, $\left.0 \mathrm{~kg} \mathrm{P} \mathrm{ha}^{-1}, 2002\right)$ to $2.6 \mathrm{t} \mathrm{ha}^{-1}$ (V4, $\left.300 \mathrm{~kg} \mathrm{P} \mathrm{ha}{ }^{-1}, 1998\right)$. In the check treatments $\left(0 \mathrm{~kg} \mathrm{P} \mathrm{kha}^{-1}\right)$ the interspecifics $\mathrm{V} 3$ $\left(1.6 \mathrm{t} \mathrm{ha} \mathrm{ha}^{-1}\right)$ and V4 (1.7 $\left.\mathrm{t} \mathrm{ha}^{-1}\right)$ had significantly $(p=0.05)$ the higher yields in 1998, especially compared to the yield of V1 $\left(0.75 \mathrm{t} \mathrm{ha}^{-1}\right)$. In 1999, these gaps were significantly $(p=0.06)$ reduced with a lowest yield observed for V5 (0.4 tha $\left.\mathrm{th}^{-1}\right)$. Interspecific $\mathrm{V} 4$ had also produced highest grain yield (1.7 $\mathrm{t} \mathrm{ha}^{-1}$ ) in the year 2000 whereas highest grain yield were produced by V1 (saltiva) in the following years (2001 and 2002) of the experiment. Generally, for V2-V5, grain yield was reduced with years of cultivation irrespective of $\mathrm{P}$ rates. However, for V1, grain yield was either slightly higher or similar with years of cultivation and $P$ rates.

Under the effects of $\mathrm{P}$ rates $(150,300$ and $\left.450 \mathrm{~kg} \mathrm{P} \mathrm{ha}^{-1}\right)$, lowest yields $\left(<2 \mathrm{t} \mathrm{ha}^{-1}\right)$ were observed for V1 $\left(0.75 \mathrm{tha}^{-1}\right)$ and V5 (1 t $\mathrm{ha}^{-1}$ ) in 1998 (Table 2). In 1999, there was a slight increased in yield (14-23\%) of V1 (saltiva) according to $\mathrm{P}$ rates while the yields declined for the interspecifics excepted the stable yield of $2.3 \mathrm{t} \mathrm{ha}^{-1}$ induced by V3 at 150 $\mathrm{kg} \mathrm{P} \mathrm{ha}{ }^{-1}$. In the subsequent years $(2000,2001$ and 2003), there was a general decreasing trend of yield for all the cultivars. Comparing the yields induced by $\mathrm{P}$ application with the one of check treatment in the latest years, there was a low residual effect for interspecific cultivars than for the saltiva (V1). However, this residual effect was not observed across experiment duration for interspecifics.

\section{Responses to $\mathbf{P}$ fertilizer}

Table 3 significantly $(p<0.05)$ confirmed the lack of residual effect of Mali PR on rice grain yield obtained in 1999, 2000, 2001 and 2002 with a positive difference of yield $\left(270 \mathrm{~kg} \mathrm{ha}^{-1}-840 \mathrm{~kg} \mathrm{ha}^{-1}\right)$ between the average grain yield of the respective years and the one of year 1998. However, the lower difference $\left(270 \mathrm{~kg} \mathrm{ha}^{-1}\right)$ was observed in year 2000 probably because of the lowest rain fall (Figure 1) observed during this cropping season. Although not significant $(p=0.878)$, the yield was slightly reduced by $(9.41 \mathrm{~kg})$ when increasing $\mathrm{P}$ rate from 300 to $450 \mathrm{~kg} \mathrm{P}$ $\mathrm{ha}^{-1}$. Thus, there is a lack of response to increasing applying rates of $\mathrm{P}$ fertilizer from 300 to $450 \mathrm{~kg} \mathrm{P} \mathrm{ha}^{-1}$.

Significant $(p<0.05)$ quadratic responses of rice yield were observed (Table 4) to the application of P for all the cultivars according to $\mathrm{P}$ rates (Dose) and highest constant terms (intercept) for V3 (1.07) and V4 (1.14). Their respective critical doses for maximum yields were $347.4 \mathrm{~kg} \mathrm{P} \mathrm{ha}{ }^{-1}$ (V3) and $292 \mathrm{~kg} \mathrm{P} \mathrm{ha}^{-1}$ (V4) during the study (5 years). However, the response surface curves (Figure 1) helped to adjust these rates to optimums of $225 \mathrm{~kg} \mathrm{P}^{-1}$ (V3) and $157.5 \mathrm{~kg}$ $\mathrm{P} \mathrm{ha}^{-1}$ (V4) considering the lack of significant difference between the respective values and the previous rates determined. Then, the 
annual application rate of $45 \mathrm{~kg} \mathrm{P} \mathrm{ha}^{-1}$ (V3) and $31.5 \mathrm{~kg} \mathrm{P} \mathrm{ha}^{-1}$ (V4) are required.

\section{DISCUSSION}

The study reveals that the interspecific cultivars are most adapted to acid soil conditions, especially during three years of continuous cropping. With reference to work done by Adepetu and Corey (1997), the lower yields observed for interspecific cultivars compared with the yield of saltiva (V1) may be attributed to most declining of soil fertility under continuous cropping. Subsequently, interspecific cultivar could have highest ability of soil nutrient uptake. This assumption corroborates the statement by Jones et al. (1997) concerning NERICA (group of 18 interspecifics) suitability for low input farming and then, for resource-limited smallholder production systems (Dingkuhn et al., 1998). However, the actual study is limiting this consideration up to three years in continuous rice cultivation compared to saltiva (WAB 56-104). The data obtained suggest that a study of soil nutrients uptake by interspecific rice can provide helpful knowledge of soil fertility management for intensification of rice production in the humid forest of West Africa.

The range $\left(1.2-1.7 \mathrm{t} \mathrm{ha}^{-1}\right)$ of yield observed after five years (2002) of cropping under $450 \mathrm{~kg} \mathrm{P} \mathrm{ha}^{-1}$ was similar to that of the first year of rice cultivation in the humid forest zone of Côte d'Ivoire in traditional farming (DCGTx, 1990). Although these yields are still low, they show a possibility to develop sedentary rice cultivation in the forest zone of West Africa by applying $450 \mathrm{~kg} \mathrm{P} \mathrm{ha}^{-1}$ at once for five years cropping. Indeed, in continuous rice cultivation in this area, the yield declines below $1 \mathrm{t} \mathrm{ha}^{-1}$. This situation induced extensive agriculture, destroying the forest ecosystem (Jurion and Henry, 1969). Thus, the actual result is an improvement of rice production on the same plot at least for five years duration. Therefore, PR application can be a component of the strategy for upland

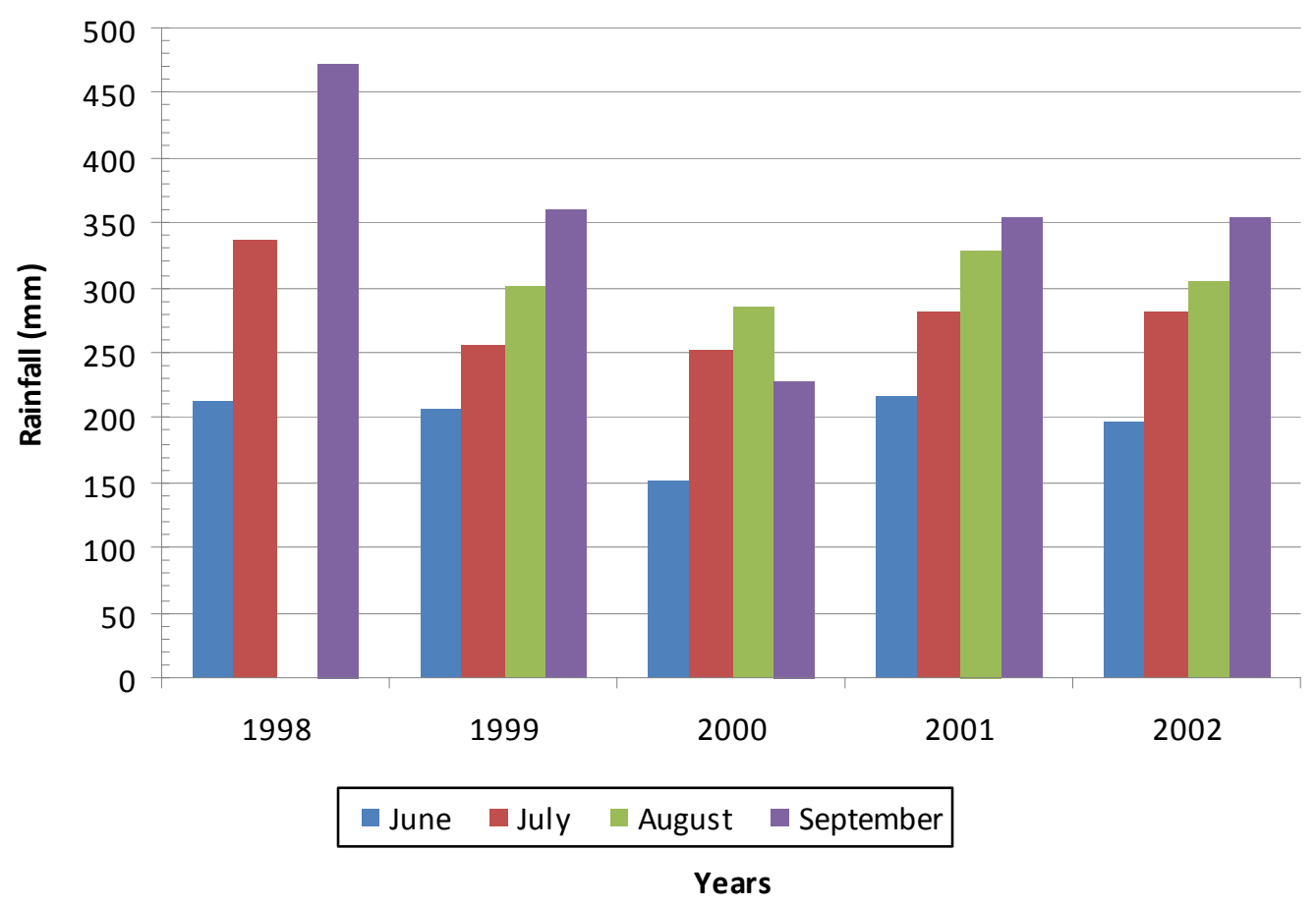

Figure 1: Rainfall during the cropping period (June, July, August and September) of each year of experiment. There is no data for august 1998. 
B. KONE et al. / Int. J. Biol. Chem. Sci. 4(3): 563-570, 2010

Table 2: Influence of Mali phosphate rock on rice grain yield.

\begin{tabular}{|c|c|c|c|c|c|c|c|c|c|c|c|c|c|c|c|c|c|c|c|c|}
\hline & \multicolumn{4}{|c|}{1998} & \multicolumn{4}{|c|}{1999} & \multicolumn{4}{|c|}{2000} & \multicolumn{4}{|c|}{2001} & \multicolumn{4}{|c|}{2002} \\
\hline & 0 & 150 & 300 & 450 & 0 & 150 & 300 & 450 & 0 & $\begin{array}{l}150 \\
\text { (kg }\end{array}$ & $\begin{array}{l}300 \\
\mathbf{P}\end{array}$ & $\begin{array}{l}450 \\
\left.\mathbf{h a}^{-1}\right)\end{array}$ & 0 & 150 & 300 & 450 & 0 & 150 & 300 & 450 \\
\hline V1 & $0.75 b$ & $1.4 \mathrm{~b}$ & $1.3 \mathrm{~b}$ & $1.4 \mathrm{c}$ & $1.0 \mathrm{ab}$ & $1.6 \mathrm{a}$ & $1.6 \mathrm{a}$ & $1.6 \mathrm{~b}$ & $0.9 \mathrm{~b}$ & $1.4 \mathrm{a}$ & $1.6 \mathrm{a}$ & $1.4 \mathrm{a}$ & $0.8 \mathrm{a}$ & $1.3 \mathrm{a}$ & $1.2 \mathrm{a}$ & $1.3 \mathrm{ab}$ & $0.8 \mathrm{a}$ & $1.4 \mathrm{a}$ & $1.5 \mathrm{a}$ & $1.7 \mathrm{a}$ \\
\hline V2 & $1.2 \mathrm{ab}$ & $2.0 \mathrm{a}$ & $2.4 \mathrm{a}$ & $2.5 \mathrm{ab}$ & $0.6 b c$ & $1.4 \mathrm{a}$ & $1.5 \mathrm{a}$ & $1.4 \mathrm{~b}$ & $1.0 \mathrm{ab}$ & $1.6 \mathrm{a}$ & $2.0 \mathrm{a}$ & $1.7 \mathrm{a}$ & $0.5 b$ & $1.2 \mathrm{a}$ & $1.2 \mathrm{a}$ & $1.3 \mathrm{ab}$ & $0.5 b c$ & $0.8 \mathrm{a}$ & $1.0 \mathrm{ab}$ & $1.3 \mathrm{a}$ \\
\hline V3 & $1.6 \mathrm{a}$ & $2.3 \mathrm{a}$ & $2.1 \mathrm{a}$ & $2.2 \mathrm{ab}$ & $1.6 \mathrm{a}$ & $1.6 \mathrm{a}$ & $2.3 \mathrm{a}$ & $2.0 \mathrm{a}$ & $1.4 \mathrm{ab}$ & $1.8 \mathrm{a}$ & $1.9 \mathrm{a}$ & $1.7 \mathrm{a}$ & $0.6 \mathrm{ab}$ & $1.1 \mathrm{a}$ & $1.3 \mathrm{a}$ & $1.4 \mathrm{a}$ & $0.6 \mathrm{abc}$ & $0.9 \mathrm{a}$ & $1.6 \mathrm{a}$ & $1.3 \mathrm{a}$ \\
\hline V4 & $1.7 \mathrm{a}$ & $2.2 \mathrm{a}$ & $2.6 \mathrm{a}$ & $2.6 \mathrm{a}$ & $1.0 \mathrm{ab}$ & $1.7 \mathrm{a}$ & $2.1 \mathrm{a}$ & $1.5 b$ & $1.7 \mathrm{a}$ & $1.9 \mathrm{a}$ & $2.0 \mathrm{a}$ & $1.5 \mathrm{a}$ & $0.7 \mathrm{ab}$ & $1.2 \mathrm{a}$ & $1.2 \mathrm{a}$ & $1.0 \mathrm{~b}$ & $0.7 \mathrm{ab}$ & $1.1 \mathrm{a}$ & $0.9 b$ & $1.2 \mathrm{a}$ \\
\hline V5 & $1.0 \mathrm{ab}$ & $1.9 \mathrm{ab}$ & $2.0 \mathrm{ab}$ & $2.1 \mathrm{~b}$ & $0.4 \mathrm{c}$ & $1.3 \mathrm{a}$ & $1.3 \mathrm{a}$ & $1.4 \mathrm{~b}$ & $0.8 \mathrm{~b}$ & $2.0 \mathrm{a}$ & $1.6 \mathrm{a}$ & $2.0 \mathrm{a}$ & $0.4 \mathrm{~b}$ & $0.9 \mathrm{a}$ & $1.1 \mathrm{a}$ & $1.3 \mathrm{ab}$ & $0.4 \mathrm{c}$ & $0.9 \mathrm{a}$ & $1.0 \mathrm{ab}$ & $1.4 \mathrm{a}$ \\
\hline Lsc & 0.67 & 0.64 & 0.73 & 0.5 & 0.56 & 0.52 & 1.1 & & 0. & 0.77 & 0.7 & 0.8 & 0.2 & 0.59 & 0.27 & 0.2 & 0.2 & 0.69 & 0.07 & 0.83 \\
\hline $\mathrm{P}>\mathrm{F}$ & 0.05 & 0.07 & 0.02 & 0.003 & 0.06 & 0.42 & 0.10 & 0.03 & 0.09 & 0.47 & 0.55 & 0.55 & 0.11 & 0.77 & 0.63 & 0.28 & 0.05 & 0.41 & 0.51 & 0.55 \\
\hline
\end{tabular}

The letters $\mathrm{a}, \mathrm{b}$ and $\mathrm{c}$ are respectively indicating the mean that are different significantly; $\mathrm{V} 1, \mathrm{~V} 2, \mathrm{~V} 3, \mathrm{~V} 4$ and $\mathrm{V} 4$ are the cultivars.

Table 3: Multiple comparisons between grain yield of years, $P$ rates and cultivars.

\begin{tabular}{|c|c|c|c|c|}
\hline & (I) & $(\mathbf{J})$ & I-J $\left(\mathbf{t ~ h a}^{-1}\right)$ & Significance \\
\hline \multirow{3}{*}{ Year } & & 2000 & 0.27 & $<0.0001$ \\
\hline & & 2001 & 0.83 & $<0.0001$ \\
\hline & & 2002 & 0.84 & $<0.0001$ \\
\hline \multirow{2}{*}{$\mathrm{P}$ rates } & & 150 & 0.13 & 0.035 \\
\hline & & 300 & $-9.41 \times 10-3$ & 0.878 \\
\hline \multirow[t]{2}{*}{ Cultivars } & V1 & $\mathrm{V} 2$ & $-7.2 \times 10^{-2}$ & 0.295 \\
\hline & & V5 & $2.13 \times 10^{-2}$ & 0.755 \\
\hline
\end{tabular}


Table 4: Quadratic regression of grain yield by $\mathrm{P}$ rate according to cultivar.

\begin{tabular}{|c|c|c|c|c|c|c|c|c|c|c|}
\hline \multirow[b]{2}{*}{ Parameter } & \multicolumn{2}{|c|}{ V1 } & \multicolumn{2}{|c|}{ V2 } & \multicolumn{2}{|c|}{ V3 } & \multicolumn{2}{|c|}{ V4 } & \multicolumn{2}{|c|}{ V5 } \\
\hline & $\beta$ & $p$ & B & $p$ & $\beta$ & $p$ & $\beta$ & $p$ & 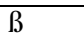 & $p$ \\
\hline Intercept & 0.88 & $<0.0001$ & 0.77 & $<0.0001$ & 1.07 & $<0.0001$ & 1.14 & $<0.0001$ & 0.67 & $<0.0001$ \\
\hline Dose & 0.004 & $<0.0001$ & 0.005 & 0.001 & 0.004 & 0.0025 & 0.004 & 0.014 & 0.005 & 0.0010 \\
\hline Dose $^{2}$ & -0.58 & 0.0007 & -0.79 & 0.019 & -0.62 & 0.0368 & -0.74 & 0.046 & -0.61 & 0.0436 \\
\hline $\begin{array}{l}p>F \\
\text { C. dose }\end{array}$ & & $\begin{array}{l}001 \\
3.4\end{array}$ & & $\begin{array}{l}001 \\
1.6\end{array}$ & & $\begin{array}{l}002 \\
7.4\end{array}$ & & $\begin{array}{l}021 \\
92\end{array}$ & & $\begin{array}{l}0001 \\
3.7\end{array}$ \\
\hline
\end{tabular}

C: critical; V1, V2, V3, V4 and V5 are cultivars.

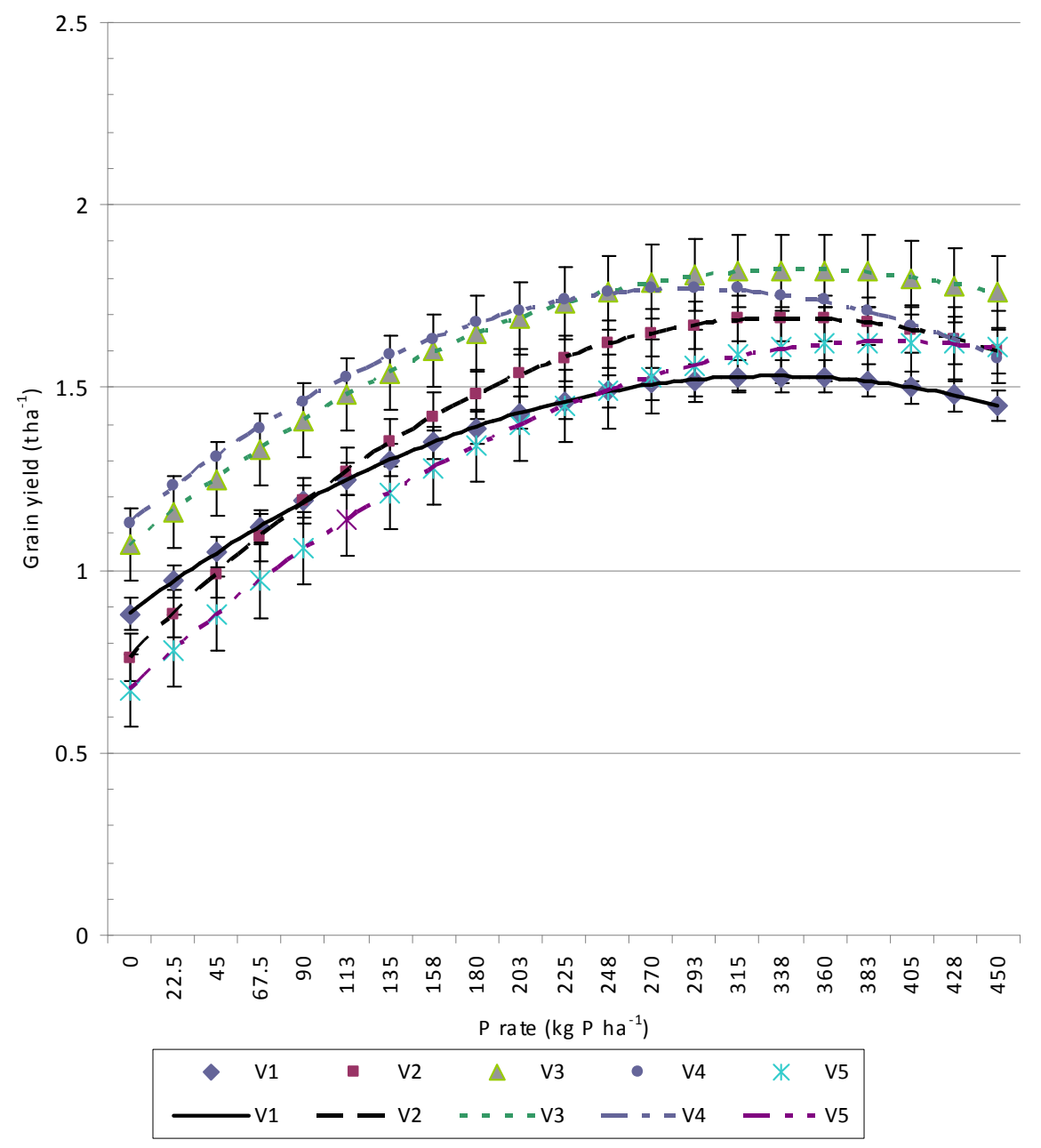

Figure 2: Yield response curves to P- rates according to cultivars (V1, V2, V3, V4 and V5). 
rice intensification in West Africa. However, the residual effect of Mali PR was varying from nill to low respectively for interspecific cultivars and V1 (saltiva) in concordance with low residual effect of PR observed by ADRAO (2000) on saltiva cultivars production in the humid forest zone of West Africa. The actual study reveals the lack of this effect for Mali PR on interspecific grain production. However, the presumption of higher nutrient uptake by these cultivars than the sativa as previously mentioned can explain the difference of PR residual effect between cultivars (interspecific vs saltiva). Futheremore, the higher $\mathrm{P}$ fixation capacity of the studied soil as demonstrated by Sahrawat et al. (2003) can also explain the result observed. Despite of this missing residual effect on interspecific yield, there is no significant difference (LSD) of yield between sativa (V1) and interspecific, especially with V3 at long-term (2005). Infact, this interspecific cultivar had highest grain yields for each $\mathrm{P}$ rate during the five years of experiment.

The lack of rice response to increasing $\mathrm{P}$ fertilizer rate as observed is corroborating with work done by Koné et al. (2010). Lower contents in $\mathrm{C}$ and exchangeable cations (Table 1) of the soil can be cited as responsible for this effect as mentioned by these authors. Moreover, applying PR fertilizer also increases soil content in $\mathrm{Ca}++$ which can reduce $\mathrm{PR}$ solubility at certain level (Chien and Menon, 1995; Hellums et al., 1989). The saltiva (V1) shows significantly $(p<0.05)$ a lower grand mean value of yield compared to the respective grand means of the interspecifics V3 $(250 \mathrm{~kg}$ $\mathrm{ha}^{-1}$ ) and V4 (230 kg ha $\left.{ }^{-1}\right)$ according to their yields difference (Table 3 ). Therefore, the interspecific cultivars as V3 and V4 are more productive than saltiva rice (WAB 56-104) on the acid soil of humid forest zone in Côte d'Ivoire. This funding is confirming the three years comparative study between the effects of triple super phosphate and Mali PR on the production of the same cultivars in the humid forest of Nigeria (Koné et al., 2009). The cultivars V3 and V4 can be used for the improvement of upland rice production in the humid forest zone of West Africa, especially for upland rice intensification.

These results confirm cultivar difference of $\mathrm{P}$ effect on crop production (Baligar, 2001; Hocking, 2001), especially for rice on the ferralsol in the humid forest zone of West Africa. Similar observations were done for NERICA nutrition in $\mathrm{N}$ and $\mathrm{P}$ in Nigeria humid forest (Oikeh et al., 2008). Lower annual rates of $31.5-45 \mathrm{~kg} \mathrm{P}^{-1}$ were revealed for Mali PR application in upland rice cultivation on acid soil. In fact, annual applications of $50-90 \mathrm{~kg}$ $\mathrm{P}$ ha $^{-1}$ was suggested (ADRAO, 2000; Somado, 2000) for the cultivation of saltiva rice. Thus, the use of interspecifics (V3 and V4) with respective recommended rates has a positive economical implication in upland rice production on acid soil.

The study pointed out a probable more ability of upland rice interspecific cultivars to highest grain yielding in low input production condition than saltiva. Further-more, interspecific V3 and V4 are revealed to have highest response of grain yield to Mali PR application at respective annual rates of $45 \mathrm{~kg} \mathrm{P} \mathrm{ha}^{-1}$ and $31.5 \mathrm{~kg} \mathrm{P}$ $\mathrm{ha}^{-1}$.

The application of Mali PR at these rates of $\mathrm{P}$ and the use of $\mathrm{V} 3$ and $\mathrm{V} 4$ are recommended for upland rice intensification on acid ferralsol in the humid forest zone of West Africa.

\section{REFERENCES}

ADRAO. 2000. Points saillants des activités. In Sur la Voie de Vaincre l'Acidité des Sols en Riziculture. Rapport annuel 1999, ADRAO (eds). ADRAO: Bouake; 23-29.

Adepetu JA, Corey RB. 1997. Changes in $\mathrm{N}$ and $\mathrm{P}$ availability and $\mathrm{P}$ fraction in Iwo soil from Nigeria under intensive cultivation. Plant and Soil, 46 (2): 309 316.

Baligar VC, Fageria NK, Ze ZL. 2001. Nutrient use efficiency in plants. Com. Soil Sci. Plant Anal., 32: 921-950.

Chien SH, Menon R. 1995. Agronomic evaluation of modified phosphate rock products: IFDC's experience. Fert. Res., 41: 197-209.

Debrah SK. 2000. La place du phosphate naturel de Tilemsi dans l'initiative pour la fertilité des sols au Mali. Rapport provisoire. IFAD-International Fund for Agricultural Devolopment Afrique, Tog. $20 \mathrm{p}$.

Dingkuhn M, Jones M.P, Johnson DE, Sow A. 1998. Growth and yield potential of $O$. sativa and $O$. glaberrima upland rice cultivars and their interspecific progenies. Field Crops Res., 57: 57-69.

Diagne A. 2008. NERICA impact and adoption in sub-saharan Africa. In Nerica: the New Rice for Africa - a Compendium (Module 14), Somado EA, Guei RG, Keya SO (eds). WARDA: Cotonou; $121-126$.

DCGTx (Direction et Contrôle des Grands Travaux). 1990. Filière riz. International Inc et DCGTx, Direction 
et control des grands travaux :Abidjan; $\mathrm{p}$. 269.

Flash E, Ouak W, Van Diest A. 1987. A comparaison of the rock phosphatemobilizing capacities of various crop species. Trop Agric., 64: 347-352.

Fardeau JC, Zapata F. 2002. Phosphorus fertility recapitalization of nutrientdepleted tropical acid soils with reactive phosphate rock: An assessment using the isotopic exchange technique. Nutrient Cycling in Agroecosystems, 63: 69 -79.

Hellums DT, Chien SH, Touchton JT. 1989. Potential agronomic value of calciumin some phosphate rocks from South America and West Africa. Soil Sci. Soc. Am. Proc., 53: 459-462.

Hocking PJ. 2001. Organic acids exuded from roots in phosphorus uptake and aluminum tolerance of plants in acid soils. $A d v$. Agron., 74: 63-93.

International Institute of Tropical Agriculture. 1989. Automated and semi-automated methods of soil and plant analysis. Manual series $\mathrm{N}^{\circ} 1$. IIITA: Ibadan.

Jones MP, Dingkuhn GK, Aluko GK, Semon M. 1997. Interspecific oryza saltiva $\times$ O. glaberrima Steud. Progenies in upland rice improvement. Euphytica., 94: 237-246.

Jurion $\mathrm{F}$ and Henry J. 1969. Can primitive farming be modernized? NEA. Ser. Hors. Institut National pour l'étude Agronomique du Congo : Bruxel.

Koné B, Diatta S, Aliou S, Akintayo I, Cisse B. 2009. Réponses des variétés de riz interspecifics du plateau aux applications de phosphate en zone de foret au Nigeria. Canadian Journal of Soil Science, 89: 555565.

Koné B, Ettien J B, Amagui, G L, Diatta S et Camara M. 2010. Effets d'engrais phosphates de différentes origines sur la production rizicole pluviale des sols acides en zone de forêt semi-montagneuse sous climats tropicaux: Cas des hyperdystric ferralsols sous jachères en Côte d'Ivoire. Etude et Gestion des Sols, 17 (1): 7-17.

Oikeh SO, Nwiliene F, Diatta S, Osiname O, Touré A, Okeleye A. 2008. Responses of upland NERCIA rice to nitrogen and phosphorus in forest Agroecosystems. Agron. J., 100(3): 735 - 741.

Sahrawat KL, Jones MP, Diatta S. 1997. Direct and residual phosphorus effects on yield and phosphorus efficiency of upland rice in an Ultisol. Nutrient Cycl. Agroecosyst, 48: 209 - 215.

Sahrawat KL, Jones MP, Diatta S, Adama A. 2001. Response of upland rice to fertilizer phosphorus and its residual value in an ultisol. Commun. Soil. Sci. Plant Anal., 32(15 \& 16): 2457-2468.

Sahrawat KL, Jones MP, Diatta S, Sika M. 2003. Long-terme phosphorus fertilizer uptake, efficiency, and recovering by upland rice on ultisol. Communications in soil science and plant analysis, 34(78): 999-1011.

Semoka JMR and Kalumuna M. 2000. Potential and constrains of using rock phosphate for crop production in Tanzania. Tanzania Soil Fertility Initiative: Background paper. Ministry of Agriculture and Coorparative, Dar es Salaam/FAO: Rome.

Somado EA. 2000. The use of phosphate rock in a rice-legume rotation system on acid soil in humid forest zone of West Africa. PhD thesis, GeorgeAugust Univ. Of Goettingen, Germany. Somado EA, Becker M, Kuehme RF. 2003. Combined effect of legumes with rock phosphorus on rice in West Africa. Agron. J., 95: 1172-1178.

Szilas C, Semoka JMR, Borggaard OK. 2007a. Can local phosphate rock replaces superphosphate on acid soils in Tanzania? Nutrient cycling in Agroecosystem, 77: 257- 268.

Szilas C, Semoka JMR, Borgaard OK. 2007b. Establishment of an agronomic database for Minjingu phosphate rock and example of its potential use. Nutrient cycling in Agroecosystem, 78:225-237. 